\title{
Stability of Demand for Money in India: Evidence from Monetary and Liquidity Aggregates
}

\author{
Purna Chandra Padhan \\ XLRI, School of Business and Human Resources \\ Post. Box No. 222, C.H. Area (E), Jamshedpur-831035, Jharkhand, INDIA \\ Tel: 91-657-398-3191(O), Fax: 91-657-222-7814 E-mail: pcpadhan@xlri.ac.in
}

\begin{abstract}
The determinants and stability of money demand functions, as per new definitions of monetary aggregates, has been analyzed in this paper. Quarterly Data from 1996Q2 to 2009Q2, for various monetary aggregates, interest rates, exchange rates, stock prices and GDP is in use. The cointegration tests, error correction mechanism, Granger causality and CUSUM tests has been applied for empirical analysis. The estimated results disclose the existence long-run and short-run relationship among the variables. Unidirectional Granger causality found from GDP and Stock Prices to monetary, new monetary as well as liquidity aggregates. Also similar result repeated from interest rates to money demand functions. The CUSUM and CUSUMQ tests support the existence of stability of each money demand functions. All the three variables, except exchange rate, affect the money demand of both types of specification.
\end{abstract}

Keywords: Monetary, New monetary, Liquidity aggregates, Cointegration, Stability tests, Causal tests

\section{Introduction}

Stability of demand for money is vital for choosing the appropriate instruments and intermediate targets of monetary policy. Essentially, it's a prerequisite for use of monetary aggregate as an intermediate target. Money demand stability implies that the quantity of money can be predictable related to various macroeconomics variables (Judd and Scadding (1982) and Friedman (1987)). In fact various macroeconomic variables such as, fiscal policy, interest rates, exchange rate, stock market, consumption expenditure, savings, investment, Import, export, etc can significantly affect the money demand. Understanding such linkages will facilitate the central bank to design the appropriate money demand function and, thus accordingly formulate and implement the appropriate monetary policy to achieve the desired objective of price stability with growth.

The issue of determinants and stability of money demand function in a transition economy has received budding interest among academician and policy makers. Stability of money demand functions is essential for stable economic growth. Several empirical studies examining the money demand function across economies are found in the macro-monetary literature. Some of the prominent studies are, Tobin (1958), Chow (1966), Goldfeld (1973), Judd and Scadding (1982), Roley (1985), McCallum and GoodFriend(1987), Laidler (1990), Goldfeld and Sichel(1990), Taylor (1991) and many more . These studies made significant contributions towards determinants and stability of money demand function. More empirical studies found across economies recently e.g. Hafer and Jansen (1991), Miller (1991), McNown and Wallace (1992) and Mehra (1993) for the USA. The paper of Lütkepohl and Wolters (1999), Coenen and Vega (2001), Brand and Cassola (2000), Holtemöller (2004b) discusses for Euro area. Arize and Shwiff (1993), Miyao (1996) and Bahmani-Oskooee (2001) examined the demand for money in the context of Japan. The studies of Drake and Chrystal (1994) for the UK; Haug and Lucas (1996) for Canada; Lim (1993) for Australia, whereas Orden and Fisher (1993) for New Zealand; Brissimis and Leventakis (1981), Bahami-Oskooee and Economiodu (2005) among few for Greece; Hsing(2007) for Croatia are pioneering in the field of demand for money. No unanimous results found in terms of specification, determinants and stability of money demand function. For example, Taylor (1991) recognized that for a high inflationary country, inflation expectation was the main determinant of money demand function than the low inflationary country.

Various aspect of money demand functions have been extensively studied in Indian context. The earlier studies of Biswas (1962), Singh (1970), Avadhani (1971), Gupta (1970, 71), Ahluwalia (1979) widely differs regarding income and interest rate as the determinant of money demand. Vasudevan (1977), Arif (1996), provides useful survey of some of the earlier studies. Applying various statistical and econometric techniques Deadman and Ghatak (1981), Sampath and Hussian (1981), Bhole (1985) and Rangarajan (1988), Nag and Upadhyay (1993) focused attention on the choice of monetary aggregates as dependent variable. Jadav (1994) established the long-run real income elasticity of broad money and semi elasticity with respect to own real rate of return. Recently Joshi and Saggar (1995), Arif (1996), Mohanty and Mitra (1999), Das and Mandal (2000) found stability of money demand functions. On the other hand, Bhoi (1995), Pradhan and Subramanian (2003) observed that financial deregulation and liberalization in the 1990s affect the empirical stability of broad money. The real GDP significantly affects money demand not interest rates, Kulkarni and Erickson (2000), thus supporting monetarists' argument of no role of interest rate in money demand. Padhan (2006), examined the money demand (M1, M3) function under liquidity adjustment facility and found that money demand functions are sensitive to real income, interest rates and to some extent exchange rates.

In India, the monetary policy formulation and implementation, which was entirely governed by the policies of Reserve Bank of India (RBI) during pre 1990's has become market driven in the post 1990's scenario. However, last 
two decade the economy is witnessed by several socio-economic-political crises, e.g. spill over effect of Asian Financial turmoil of 1997, Indo-Pak Kargil War, the devaluation of rupees against US dollar, US sub prime crisis spill over effect, global recession, the stock market crash, spiral increase in inflation, general elections, internal rebellion of various activists groups and many more. This has complicated the task for RBI to conduct and implement monetary policy in a challenging environment and cope up with the pace of transition from an administered system to a market based process. Choosing the appropriate intermediate target, instruments and operating procedures of monetary policy has become tedious. Since mid 80's monetary target is still the intermediate target of monetary policy even though RBI has adopted multiple indicator approach ever since mid 90's. An effective and transparent monetary policy requires a strong relationship between output, income, prices, interest rates etc. and other macroeconomic variables. Therefore such transitions and challenges raise concerns over the determinants and stability of the money demand.

To summaries, most of these studies applied either narrow money $\left(\mathrm{M}_{1}\right)$ or broad money $\left(\mathrm{M}_{3}\right)$ as measures of monetary aggregates and mixed evidence found on stability. Recently, RBI working group on money supply (1998) came up with alternative monetary aggregates such as $\mathrm{L}_{1}, \mathrm{~L}_{2}, \mathrm{~L}_{3}, \mathrm{NM}_{1}, \mathrm{NM}_{2}$, and $\mathrm{NM}_{3}$ (Note 1). Although, broad money $\left(\mathrm{M}_{3}\right)$ is widely used for policy analysis, other monetary aggregates are quite relevant for the economy, as they provide unique information. To our mind, none of the study considered such empirical specification of money demand functions. There is also paucity of study to examine the impact of factors such as stock price, exchange rates in affecting money demand functions. Instead of using proxy variable (IIP) the study uses actual quarterly GDP data for income and two different interest rates (call money rate i.e. market determined interest rate and 91Day Treasury bill rate i.e. policy rate). In view of this, the objective of the paper is to study determinants and stability of money demand applying various monetary (old and new) and liquidity aggregates in this context of India.

The rest of the paper is divided into following sections. The Section 2 specifies model specification and methods of estimation of money demand function. Section 3 discusses the empirical results and section 4 concludes.

\section{Model Specifications and Methods of Estimation}

While formulating the demand for money we have started with the traditional quantity theory of money expressed as MV = Py (Note 2). As suggested by Friedman (1987) including various determinants of money demand the QTM, a simple money demand function, can be stated as $(\mathrm{M} / \mathrm{P})^{\mathrm{d}}=\mathrm{f}(\mathrm{y}, \mathrm{r}, \mathrm{E}, \mathrm{S})$, where $\mathrm{M}$ is money stock, $\mathrm{P}$ is general price level, $\mathrm{V}$ is velocity of circulation of money, $\mathrm{y}$ is real income, $\mathrm{r}$ is interest rate, $\mathrm{E}$ is exchange rate, $\mathrm{S}$ is stock price. The exchange rate and stock price is included as additional determinants of demand for money. The rationality is that foreign exchange and stocks constitutes a part of portfolio of economic agents. Depreciation in exchange rate may result in further depreciation of the currency, which will force individuals to hold money as foreign currency to avoid possible losses. Similarly, expectations of currency depreciations may reduce money demand either due to substitution effect or wealth effect, Arango and Nadiari (1981). On the other hand stock price could be another variable affecting money demand functions possibly due to wealth effect and substitution effect Friedman (1988). For example, any increase in stock price might increase the nominal wealth; as returns on investment increases. This might induce people to hold more money and hence demand for money balances increases. Similarly, as stock price increases people might reshuffle the portfolio and prefer to hold large chunk of other attractive and lucrative equities in the portfolios. It indicates that net affect of stock price could be either $+v e$ or $-v e$. Thus the demand for real money balances as a function of real income, interest rate, real stock price, real exchange rate can be specified as (Note 3)

$(\mathrm{M} / \mathrm{P})_{\mathrm{t}}^{\mathrm{d}}=\beta_{0}+\beta_{1}(\mathrm{Y} / \mathrm{p})_{\mathrm{t}}+\beta_{2} \mathrm{r}_{\mathrm{t}}+\beta_{3} \mathrm{E}_{\mathrm{t}}+\beta_{4} \mathrm{~S}_{\mathrm{t}}+\varepsilon_{\mathrm{t}}$

Where, $\mathrm{M}$ is nominal money supply at time t., $\mathrm{P}$ is the price level(WPI), $\mathrm{Y}$ is nominal income, $\mathrm{r}_{\mathrm{t}}$ is short term interest rate and $E_{t}$ is the real exchange rate, $S_{t}$ is the real stock price at time $t$. In the equation, $(M / P)_{t}{ }_{t}$ represents the real money balance and $(\mathrm{Y} / \mathrm{p})_{\mathrm{t}}$ is the real income at time t. Theoretically, demand for money is directly related with real income and indirectly with interest rates. But the sign of the exchange rate and stock price in uncertain. So by convention, the values of the coefficient of income $\left(\beta_{1}\right)$ should be positive and interest rate $\left(\beta_{2}\right)$ is negative but for exchange rate $\left(\beta_{3}\right)$ and stock price $\left(\beta_{4}\right)$ it could be either negative or positive. It calls for empirical estimation of money demand functions and tests its stability.

The equation (1) can be estimated by multiple linear regression models, although regression model does not explain the dynamic relationship among the specified variables. The relationship could also be spurious. The cointegration test of Johansen-Juselius (1990) possibly avoids the problem by allowing feedback relationship and provides the long-run equilibrium relationship among variables.

The equation 1 can be expressed as a vector of variables, where each variable might be dynamically interrelated. Their long-run and short-run equilibrium relationship can be examined using cointegration and error correction model respectively. Technically speaking the money demand equation can be considered as a cointegrating equation. The estimation of Johansen -Juselius cointegration equation is based on Vector auto regression model estimated through maximum likelihood estimation procedure (Note 4). Johansen (1988, 1991), Johansen's-Juselius (1990, 1992) methodology is design to determine the number of cointegrating vector in the VAR system. The methods specify two test statistics in order to test the number of cointegrating vectors. Those are $\lambda$ max (the maximum eigen value statistics) and $\lambda$ trace statistics. The first step of testing cointegration is to tests whether the series are 
stationary or not i.e. I (1) or I (0). Then apply the cointegration for non-stationary series i.e the series at levels if the variables are I (1). We can test the integration of the series by applying Phillips-Peron, PP ( 1988) and KPSS ( 1992) tests. Once the series are cointegrated they follow equilibrium pattern in the long run. However, in the short-run they might depart from each other resulting in dis-equilibrium. This can be explained through corresponding error correction model by including stationary residuals from the cointegrating vectors and include its one period lagged values ( ECt-1) in an error correction model.

The ECM can be specified as,

$\Delta M_{t}=\beta 0+\sum_{j=1}^{n} \beta_{1 j} \Delta M_{t-j}+\sum_{j=0}^{n} \beta_{2 j} \Delta y_{t-j}+\sum_{j=0}^{n} \beta_{3 j} \Delta r_{t-j}+\sum_{j=0}^{n} \beta_{4 j} \Delta E_{t-j}+\sum_{j=0}^{n} \beta_{5 j} \Delta S_{t-j}+\lambda E C_{t-1}+u_{t} \ldots \ldots \ldots \ldots \ldots \ldots$ (2)

Where, $\lambda$ is the coefficient of error correction term. It denotes the speed of convergence towards equilibrium and provides the direction of equilibrium. The expected sign of the coefficient is negative. It means if the model is out of equilibrium, then demand for real money balance come forward from below to restore the equilibrium in the next period. If $\lambda$ is not statistically significant, implying that the coefficient is equivalent to zero, hence the dependent variable adjusts to the changes in independent variables in the same period during short run.

We have applied the Granger causality tests to evaluate the temporal causality. Granger causality test says that if the variables are cointegrated then there exists a necessarily causal relationship among them at least in one direction. The causality can be tested using F statistics. Under the null hypothesis of no causality (e.g. from Y to X), if calculated F statistics is greater than critical F statistics with appropriate degrees of freedom and significance level, then reject the null hypothesis against alternative hypothesis.

Finally, we have applied CUSUM and CUSUMQ tests, proposed by Brown et. al. (1975) to tests the stability of the long-run and short-run coefficients. If the plot of CUSUM or CUSUMQ stays with in the $5 \%$ significance level, then the coefficients estimates are said to be stable (Note 5).

\section{Data and Empirical Analysis}

\subsection{Data}

Various alternative definitions of monetary aggregates such as narrow money (M1), broad money (M3) and liquidity aggregates $\mathrm{L}_{1}, \mathrm{~L}_{2}$, new monetary aggregates $\left(\mathrm{NM}_{3}\right)$ is applied for empirical analysis(Note 6).

Weighted average call money rate (henceforth CMR) Mumbai and 91 Day Treasury bill rate (henceforth TBR) are considered for interest rates and Real effective exchange rate (reert) trade based (36- country weights) is for exchange rate. For stock price, CNXNifty is considered. Real income is measured by GDP at constant price. The empirical analysis is carried out applying quarterly data from 1996 Q2 to 2009 Q2. The period has been chosen based on availability of the quarterly data; collected from the Handbook of Statistics on Indian Economy. The quarterly data for CMR and TBR which is not available are extrapolated from monthly data. The real values are generated by deflating the nominal variable with the wholesale price index (WPI). After estimating the variable in real term, all the variables are expressed by natural logarithms.

\subsection{Descriptive Statistics and Correlations}

Preliminary understating of data structure can be analyzed through descriptive statistics and correlations coefficients. The results of summary statistics for all variables expressed in natural logarithms are given in table 1 . The results reveal that except 91 day Treasury bill rate (TBR) and CNXNifty other variables follow normal distribution as represented by JB test and corresponding probability values. The null hypothesis of normal distribution for both the variables is rejected at $1 \%$ and $10 \%$ significance level. Since the sample size is very small i.e. 53 only, so such type of conclusion is irrelevant. Skewness and Kurtosis support the same conclusion, whose value for a normal distribution are 0 and 3 respectively. Except TBR and CNXNifty other variables are normally distributed. When the variable is normally distributed, it does not follow random walk process and hence become easy to establish the relationship between such variables.

The variability of various monetary aggregates is similar. The coefficient of variations is lowest for TBR indicating that it's less volatile. The correlation coefficient of GDP and Stock price with money aggregates are highly correlated. Interest rate is moderately correlated with the monetary aggregates. Informally, the money demand functions are highly correlated with the income, interest rate and stock market. The sign of the correlation coefficient are obtained as per expectations. Although correlation coefficient between exchange rate and monetary aggregates are very less, it does not provide cause and effect relationship between variables. The demand function can be estimated through regression analysis.

\subsection{Regression Analysis}

The money demand equation 1 can be estimated through multiple linear regression model. We have estimated 10 different regression equations for 5 different alternative combinations of monetary aggregates using 2 types of interest rates separately. It's because the model suffers from multicollinearity problem as the correlation coefficient between CMR and TBR is very high i.e 0.858 and VIF is 3.788. The results are reported in table 2. The regression model is estimated with Newey-West HAC standard error and covariance with lag truncation equal to 3 to avoid the possibility of unknown heteroscedasticity and autocorrelation problem. The regression results using CMR and TBR separately are reported in panel A and B respectively. In both the panel, income and interest rates significantly affect money demand function irrespective of model specification. The coefficients of income are statistically significant at $1 \%$ significance level applying $t$ test. Except for $\mathrm{M}_{3}$ (which is significant at $5 \%$ significance level) in panel $\mathrm{A}$, the 
coefficient of interest rate are statistically significant at $1 \%$ significance level. The results are consistent with Keynesian theory of demand for money as the sign of the coefficient; real income and interest rate are consistent and statistically significant. On the other hand, coefficient of stock price is statistically significant at $1 \%$ significance level only for $\mathrm{M}_{1}$ money demand function and none other. But exchange rate is not statistically significant in either case. Hence both the variables do not statistically significantly affect money demand. The obtained coefficients are elasticity of money with respect to respective variables. For example the income elasticity of $\mathrm{M}_{3}$ is equal to 1.32 , i.e. more elastic. The regression results are robust due to high $\mathrm{R}^{2}$, Significant $\mathrm{F}$ statistics, no autocorrelation and no heteroscedasticity problem. Of course, the limitation is that multiple regression model does not explain dynamic relationship among variables. The cointegration techniques e.g. Johansen-Juselius (1990) applied here can overcome such problem (Note 7).

3.4 Stationary of the Series

If any linear combination of two or more non-stationary series is stationary then the series are said to be cointegrated. The application of cointegration needs prior checking of stationary properties. Phillips-Perron (PP, 1988) and Kwiatkowsk, Phillips, Schmidt, and Shin (KPSS, 1992) unit root tests are applied. The former test addresses the issue of possible serial correlation in the regression model and tests the hypothesis. The later is a confirmatory test. The results are reported in table 3 at level and first difference of the variables. The models are estimated including a constant (C) and with constant \& trend (C \& T) term in the regression equations separately. For PP and KPSS tests the brackets represent the bandwidth of Newey- West using Bartlett kernel. For PP tests p values are in the parenthesis.

The PP tests assume the null hypothesis of unit root against the alternative of stationary. On the other hand KPSS is a confirmatory test, which assumes the null hypothesis of stationary against the alternative of non-stationary. For all variables at level the null hypothesis is accepted. However, for the variables at first difference, we reject the null hypothesis of unit root at $1 \%$ significance level for by both the PP and KPSS test of alternative model specification. Thus variables are stationary at first difference and non-stationary at level. Hence we can apply cointegration tests at level data.

3.5 Cointegration Results

The next step is to apply the multivariate cointegration test of Johansen $(1988,1991)$ and Johansen's-Juselius $(1990$, 1992), estimated through maximum likelihood estimation procedure. Two tests statistics such as $\lambda$ trace and $\lambda$ maximum eigen value is used to determine the number of cointegration vector. For $\mathrm{n}$ variable cases if at least one $(\mathrm{r}=1)$ cointegrating vector is present, it is sufficient to conclude that the variables are cointegrated. The number of cointegrating vector is estimated through VAR model for which it is necessary to specify the number of lag length in the autoregressive process. We have started with 1 lag and maximum of 8 is taken in the process. The lag length of 4 is chosen based on Akaike Information Criteria, Schwarz Bayesian Criteria and log likelihood ratio tests, which is theoretically and practically justified. The robustness of the model has also been checked using ARCH, LM, JB, Heteroscedasticity tests (Note 8).

Once optimal lag length is determined then next step is to apply cointegration test. The obtained results are reported in table 4. Panel A specify the cointegration equation with constant term, whereas panel B specify model with the linear deterministic trend term. In both the cases, we have estimated 10 cointegrating equations with two different interest rates. In panel A , irrespective of money demand specification with any interest rates, the null hypothesis of zero cointegrating vector $(\mathrm{r}=0)$ is rejected against the alternative of at least one cointegrating vector at $5 \%$ significance level. The same result is repeated in panel B also. For both the model we found minimum one cointegrating vector. Further, testing more number of cointegrating vectors, we might obtain different results, as shown in the table. This is evident from both trace and eigen value statistics. For example, the null hypothesis of $\mathrm{r}=2$ cointegrating vector is rejected and alternative of 3 cointegrating vector is accepted for $\mathrm{M}_{1}$ money demand function with constant term. Similarly for $\mathrm{NM}_{3}$ money demand function with trend, the null hypothesis of $\mathrm{r}=1$ cointegrating vector is rejected at 5\% significance level and alternative of $\mathrm{r}>2$ is accepted. The result strongly supports the presence of one cointegrating vector for both the demand functions. Therefore, we can conclude that cointegration exists between variables and hence in the long-run they are related.

3.6 Error Correction Mechanism

If the variables are cointegrated, it need not necessarily mean that in the short-run they are always in equilibrium. This departure from the equilibrium relationship in the short-run is explained through error correction term. The error correction term is obtained from the residuals terms of cointegrating equations and plugged into the cointegrating equation with lagged term in first difference. The specified error correction model 2 is estimated using OLS methods. The results are reported in table 6. The details of ECM results are not provided here except the coefficient of Error correction term due to space consumption and may be available upon request. It means except $\mathrm{M}_{3}$ money demand equation the sign of coefficient of error correction term is negative which is as per expectations. It implies that the specified money demand function adjust from below to restore the equilibrium in the immediate next period. Since other coefficients are statistically insignificant, implying that they are equivalent to zero. So the money demand function reacts to the changes in independent variables with the same period to restore equilibrium. However, if ECM term is negative, then monetary aggregates comes from above to restore equilibrium. The result 
indicates that all the variables are related in the short run and therefore the short-run causality can be explained through Granger causality tests.

3.7 Granger Causality Tests

The bivariate Granger causality test is applied for testing causality. According to Engel-Granger (1987), if the variables are cointegrated, then they are necessarily causally related at least in one direction. Granger causality applied for stationary series only, so we have estimated this for variables with first difference. The bivariate Granger causality tests results are reported in table 6. Accordingly the null hypothesis of GDP does not Granger cause monetary aggregates have been rejected for all types of money demand functions at various significance level, as reported by $\mathrm{F}$ statistics and corresponding $\mathrm{P}$ values. It implies that real income Granger causes money demand but not the reverse except for L2. Except L2 unidirectional causality found from real income to real money balances. Bi-directional relationships exist for real income and real L2 money balance. There is also unidirectional causality from real money to both the interest rates. It implies that call money rate reacts (also TBR) for any change in money demand not the reverse. Unidirectional causality found from stock price to money demand functions as the null hypothesis is rejected at various significance level. No causal relationship notices in either direction between exchange rate and real money balances. The result is consistent with regression results, also justified as per the magnitude and sign of coefficients are concerned.

\subsection{Stability Tests}

Once variables are cointegrated and causal relationship established, then stability of the demand for money can be tested applying CUSUM and CUSUMQ tests. From cointegrating equation we can obtain residuals. Considering the coefficients of residual with one period lagged term, we estimate an error correction model (with appropriate lagged term, here it is 4) and then apply both CUSUM and CUSUMQ test on the residual of error correction term. The equation 2 specifies ECM and can be estimated by OLS method. Then apply the CUSUM and CUSUMQ tests on the residual. If graphical plot of the CUSUM and CUSUMQ stays within 5\% significance level, then coefficient estimators are said to be stable. The estimated result for each money demand specification with both CMR and TBR are represented in both Panel A and B respectively. From fig 1 it is clear that graphical plot of the CUSUM and CUSUMQ stays with in critical band of $5 \%$ for $\mathrm{M}_{1}, \mathrm{~L}_{1}$, and $\mathrm{L}_{2}$ demand for money. It indicates that the demand for money is stable. However although CUSUMQ tests for $\mathrm{M}_{3}$ and $\mathrm{NM}_{3}$ money demand are slightly out side the band ( during mid 2006 to 2007) most of the cumulative sum of recursive residual squares are with in $5 \%$ confidence limit. It indicates that both $\mathrm{M}_{3}$ and $\mathrm{NM}_{3}$ demand for money is also relatively stable.

\subsection{Money Demand Functions}

The estimated money demand functions through regression analysis are reported in table 2 . The estimated demand functions suggest existence of a stable relationship between real money balances with real income, real interest rate, and to some extent real exchange rate and stock price. From the equations we can find the elasticity of demand for real money balances. The income elasticity of demand with respect to $\mathrm{M}_{1}, \mathrm{M}_{3}, \mathrm{~L}_{1}, \mathrm{~L}_{2}$ and $\mathrm{NM}_{3}$ is $1.014,1.32,1.39$, 1.387 , and 1.397 respectively. The positive sign is consistent with the theory because as income increases the demand for money increases. The interest (CMR ) elasticity of money demand with respect is $\mathrm{M}_{1}, \mathrm{M}_{3}, \mathrm{~L}_{1}, \mathrm{~L}_{2}$ and $\mathrm{NM}_{3}$ is $-0,118,-0.127,-0.143,-0.140$ and -0.145 respectively, which is also consistent with theory. The elasticity of money demand for $\mathrm{M}_{1}, \mathrm{M}_{3}, \mathrm{~L}_{1}, \mathrm{~L}_{2}$ and $\mathrm{NM}_{3}$ with respect to exchange rate is $0.006,0.188,0.284,0.288$ and 0.173 respectively. Similarly the elasticity of money demand for $\mathrm{M}_{1}, \mathrm{M}_{3}, \mathrm{~L}_{1}, \mathrm{~L}_{2}$ and $\mathrm{NM}_{3}$ with respect to stock price is $0.165,0.038,0.046,0.046$ and 0.083 respectively. Elasticity of money demand with respect to real income is elastic but inelastic for interest rate, exchange rate and stock price. The results are consistent with theories of demand for money.

\section{Conclusion}

The paper started with a discussions on the specification, estimation and stability of the demand for money with respect to various monetary (old and new) and liquidity aggregates. The money demand function specified including exchange rate and stock price in addition to income and interest rates. For empirical testing of the same it uses quarterly data. All the series expressed in natural logarithms are stationary at first difference. The cointegration result shows the presence of more than one cointegrating vector for all types of money demand functions, supporting the long-run equilibrium relationship among variables. Similarly ECM also supports the short-run dynamic properties of money demand functions. Unidirectional causality found from GDP and Stock Prices to monetary, new monetary and liquidity aggregates through Granger causality test. Similarly unidirectional causality is also noticed from interest rates to money demand functions. The CUSUM and CUSUMQ tests show that all the alternative specification of money demand functions is stable. The paper also concludes that except exchange rate, all the other variables significantly affect the money demand function.

\section{References}

Ahluwalia, I. J. (1979). Behavior of prices \& output in India: A macro-econometric approach. (1 ${ }^{\text {st }}$ ed.) Macmillan Company of India, Mumbai.

Arango, S. \& Nadiri, M. I. (1981). Demand for money in open economies. Journal of Monetary Economics, 7, 69-83.

Arif, R. R. (1996). Money demand stability: myth or reality - an econometric analysis. Development Research Group Study 13, Reserve Bank of India. 
Arize, A. C. \& Shwiff, S. S. (1993). Cointegration, real exchange rate \& modeling the demand for broad money in Japan. Applied Economics, 25 (6), 717-726.

Avadhani, V. A. (1971). Money demand in the corporate sector. Indian Economic Journal, 18, 552-562.

Bahmani-Oskooee, M. \& Economidou, C. (2005). How stable is demand for money in Greece? International Economic Journal, 19(3), 461-472. .

Bahmani-Oskooee, M. (2001). How stable is M2 money demand function in Japan? Japan \& the World Economy 13, 455-461.

Bhoi, B. K. (1995). Modeling buffer stock money : An Indian experience. RBI Occasional Papers, 16(1).

Bhole, L. M. (1985). Impacts of monetary policy ( $1^{\text {st }}$ ed.). Himalayan Publishing House, Bombay.

Biswas, D.(1962). The Indian money market: an analysis of money Demand. Indian Economic Journal, 3, 9, 308-23.

Brand, C. \& Cassola, N. (2000). A money demand system for euro area M3. ECB Working Paper 39, 1-49.

Brissimis, S. N. \& Leventakis, J. A. (1981). Inflationary expectations and the demand for money: the Greek experience. Kredit and Kapital, 4, 482-489.

Brown, R. L, Durbin, J. \& Evans, J. M. (1975). Techniques for testing the constancy of regression relationships over time. Journal of the Royal Statistical Society, 37, 149-163.

Carlson, J. B., Hoffman, D. L., Keen, B. D. \& Rasche, R. H. (2000). Results of a study of the stability of cointegrating relations comprised of broad monetary aggregate. Journal of Monetary Economics, 46, 345-83.

Chow, G. C. (1966). On the long-run \& short-run demand for money. Journal of Political Economy, 74, $111-31$.

Coenen. G. \& Vega, J. L. (2001). The demand for M3 in the Euro area. Journal of Applied Econometrics, 16, 727-748.

Das, S. \& Mandal, K. (2000). Modeling money demand in India: testing weak, strong \& super exogeneity. Indian Economic Review, 35, 1-19.

Deadman, D. \& Ghatak, S.A. (1981). On stability of money demand functions in India. Indian Economic Journal, 29, 1, 41-54.

Dickey, D. A. \& Fuller, W. A. (1981). Likelihood ratio statistics for autoregressive time series with a unit root. Econometrica, 49, 1057-1072.

Drake, L. \& Chrystal, K. A. (1994). Company-sector money demand: new evidence on the existence of a stable long-run relationship for the UK. Journal of Money, Credit, \& Banking 26, 479-494.

Engel, R. F. \& Granger, C. W. J. (1987). Co-integration \& error-correction: representation, estimation, \& testing. Econometrica, Vol. 55, 251-276.

Friedman, M. (1987). The quantity theory of money. In J Eatwell, M Milgate and P Newman (Eds.), The new Palgrave: A Dictionary of Economics, Vol. 4. London: McMillan Press.

Friedman, M. (1988). Money \& the Stock Market. Journal of Political Economy, 96(2), 221-245.

Goldfeld, S. \& Sichel, D. (1990). The demand for money. In Handbook of Monetary Economics, By B. M. Friedman and F. H. Hahn, (Eds.). Vol. 1.Amsterdam: North-Holland.

Goldfeld, S. M. (1973). The demand for money revisited. Brookings Papers on Economic Activity, 3, $577-638$.

Gonzalo, J. (1994). Five alternative methods of estimating long-run equilibrium relationships. Journal of Econometrics, 60, 203-233

Gupta, K. L. (1971). The demand for money in India-A reply. Journal of Development Studies, 7, 2, $202-210$.

Gupta, K. L. (1970). The demand for money in India-further evidence. Journal of Development Studies, 6, 2, 59 168.

Hafer, R. W. \& Jansen, D. W. (1991). The demand for money in the United States: evidence from cointegration tests. Journal of Money, Credit, and Banking, 23, Pp. 155-168.

Haug, A. A. \& Lucas, R. F. ( 1996). Long-term money demand in Canada: in search of stability. Review of Economics \& Statistics, 78, 345-348.

Holtemöler, O. (2004b). A monetary vector error correction model of the euro area and implications for monetary policy. Empirical Economics, 29, 553-574.

Hsing, Y. (2007). The roles of the exchange rate and the foreign interest rate in Estonia's money demand function and policy implication. Applied Financial Economics Letters, 3, 51-54.

Jadav, N. (1994). Monetary economics for India. (1 $1^{\text {st }}$ eds). Delhi: Macmillan India Limited.

Johansen, S. \& Juselius, K. (1992). Testing structural hypotheses in a multivariate cointegration analysis of the PPP and The UIP for UK. Journal of Econometrics, 53, 211- 244.

Johansen, S. \& Juselius, K. (1990). Maximum likelihood estimation and inferences on cointegration-with applications to the demand for money. Oxford Bulletin of Economics and Statistics, 52.169-210.

Johansen, S. (1988). Statistical analysis of cointegrating vectors. Journal of Economic Dynamics and Control, 12 , 321-354.

Johansen, S. (1991). Estimation and hypothesis testing of cointegrating vectors in gaussian vector autoregressive models. Econometrica, 59, 1551-1580.

Joshi, H., \& Saggar, M. (1995). The demand for money in India: stability revisited. Reserve Bank of India Occasional Papers, 16, 2, 79-100. 
Judd, J. L. \& Scadding, J. L. (1982). The search for a stable money demand function: a survey of the post-1973 literature. Journal of Economic Literature, 20, 93-1023.

Kulkarni, G. K. \& Erickson, E. L. (2000). Demand for money stability revisited: a case for India. The Indian Journal of Economics, 71, 1, 23-47.

Kwiatkowski, D., Phillips, P.C.B, Schmidt, P. \& Shin, Y. (1992). Testing the null hypothesis of a stationary against the alternative of a unit root: how sure are we that economic time series have a unit root? Journal of Econometrics, 54, 159-178.

Laidler, D. (1990). The demand for money: theories, evidence, and problems, $\left(3^{\text {rd }}\right.$ Eds.). New York: HarperCollins.

Lim, G. C. (1993). The demand for the components of broad money: error correction and generalized asset adjustment systems. Applied Economics, 25, 8, 995-1004.

Lütkepohl, H. \& Wolters, J. (Eds.) (1999) 'Money Demand in Europe. Heidelberg: Physica.

McCallum, B. T. \& Goodfriend, M. S. (1987). Demand for money: theoretical studies. In The New Palgrave: $A$ Dictionary of Economics, (vol. 1. pp. 775-781). London: Macmillan Press Ltd.

McNown, R. \& Wallace, M. S. (1992). Cointegration tests of a long-run relation between money demand \& the effective exchange rate. Journal of International Money and Finance, 11, 1, 107-114.

Mehra, Y. P. (1993). The stability of the $\mathrm{m} 2$ money demand function: evidence from an error-correction model. Journal of Money, Credit, and Banking, 25, 455-460.

Miller, S. M. (1991). Monetary dynamics: an application of cointegration and error-correction modeling. Journal of Money, Credit, and Banking, 23, 139-168.

Miyao, R. ( 1996). Does a cointegrating $\mathrm{m} 2$ demand relation really exist in Japan? Journal of the Japanese \& International Economics, 10, 169-180.

Mohanty, D. \& Mitra, A. K. (1999). Experience with monetary targeting in India. Economic and Political Weekly, $16-22 / 23-29.34,3 \& 4,123-32$.

Nag, A. K. \& Upadhyay, G. (1993). Estimation of money demand function: a cointegration approach. Reserve Bank of India Occasional Papers, 14, 47-66.s

Orden, D. \& Fisher, L. A. ( 1993). Financial deregulation and the dynamics of money, prices and output in New Zealand and Australia. Journal of Money, Credit, and Banking, 25, 273-292.

Osterwald-Lenum, M. (1992). A note with quintiles of the asymptotic distributions of the maximum likelihood cointegration rank tests statistics. Oxford Bulletin of Economics and Statistics, 54, 461-71.

Padhan, P. C. (2006). A cointegration approach to the demand for money under liquidity adjustment facility in India: a note. Indian Journal of Economics and Business, 5, 1,78-88.

Phillips, P.C.B. \& Perron, P. (1988).Testing for a unit root in time series regression. Biometrica, 75, 335-346.

Pradhan, B. K \& Subramanian, A. (2003). On the stability of demand for money in a developing economy some empirical issues. Journal of Development Economics, 72, 1, 335-351.

Rangarajan, C. (1985). Money, output and prices. Dr. S. K. Muranjan Memorial Lecture, Reserve Bank of India Bulletin, December.

Rangarajan, C. (1988). Issues in monetary management. Presidential Address: The $71^{\text {st }}$ annual conference of the Indian Economic Association, Delhi.

R.B.I. (1998). A working group on Money Supply: Analytics and Methodology of Compilation. Mumbai: Reserve Bank of India.

Roley, V. V. (1985). Money demand predictability. Journal of Money, Credit, and Banking, 17, 2, 611-641.

Sampath, R. K., \& Hussain, Z. (1981). Demand for money in India. The Indian Economic Journal, 24, 1, 41 - 54.

Singh, B. (1970). Price stability and money supply during fourth five year plan. Indian Economic Journal, 17, 4-5, 469-480.

Taylor, M. P. (1991). The hyperinflation model of money demand revisited. Journal of Money, Credit, and Banking, $1,23,327-351$.

Tobin, J. (1958). Liquidity preference as behavior toward risk. Review of Economic Studies, 25, 65-86.

Vasudevan, A. (1977). Demand for money in India - a survey of literature. Reserve Bank of India Occasional Papers, 2 (1), 58-83.

Notes

Note 1. M1 = Currency with the Public + Demand Deposits with the Banking System + 'Other' Deposits with the RBI.

M2=M1 + Savings Deposits of Post office Savings Bank

M3 = M2 + Term Deposits of residents with a contractual maturity of over one year with the Banking System + Call/Term borrowings from 'Non-depository' Financial Corporations by the Banking System

NM2 = currency and residents' short-term bank deposits which would stand in between narrow money (M1) (which includes only the non-interest bearing monetary liabilities of the banking sector) and broad money (M3) (an all encompassing measure that includes long-term time deposits). NM3= Currency with the public + Demand Deposits with Banks + Time Deposits with Banks- FCNR (b) and RIB deposits + 'Other' Deposits with RBI +Other borrowings by Banks.

L1= M3 + all Post Office Deposits with the Post Office Savings Banks( Excluding National Savings Certificate) 
$\mathrm{L} 2=\mathrm{L} 1+$ Term Deposits with FIs + Term Borrowing by FIs + CDs issued by FIs

L3 $=$ L2 + Public Deposits with NBFCs

Note 2.According to the standard text books, real income determines the demand for money in the classical sense as money is demanded for transaction purpose, whereas for Keynesian it is real income and interest rate as people demand money for transaction, precautionary and speculative purpose. On the other hand, Friedman has given a list of factors affecting money demand such as stock, bonds, etc. which generated wealth. Similar exchange rate also determines the demand for money because of substitution as well as wealth effect.

Note 3. According to Rangarajan (1985),it is possible to build into such a formulation the lagged impact of the factors that influence the money holding

Note 4. Since this is widely applied technique, we are not discussing the details of it. Once can refer a stranded text book on Time series Econometrics. In our earlier version of the paper Padhan (2006) we have discuses about this procedure elaborately.

Note 5. The significance level is portrayed by two straight lines whose equations are given in Brown et.al (1975)

Note 6. NM2 and L2 are not considered due to lack of required data.

Note 7. Gonzalo (1994) analyzed the statistical performance of three cointegration tests such as, Engel-Granger, the Stock and Watson tests, and Johansen's test and found that Johansen's is found to be superiors to the other tests under consideration.

Note 8 . The results can be obtained from the author upon request.

Table 1. Descriptive Statistics and Correlations

\begin{tabular}{|c|c|c|c|c|c|c|c|c|c|c|}
\hline Descriptive Statistics & $\mathrm{M}_{1}$ & $\mathrm{M}_{3}$ & $\mathrm{~L}_{1}$ & $\mathrm{~L}_{2}$ & $\mathrm{NM}_{3}$ & GDP & CMR & TBR & REERT & CNXNifty \\
\hline Mean & 3.45 & 3.990 & 4.002 & 4.004 & 3.977 & 5.541 & 0.813 & 0.820 & 1.994 & 0.999 \\
\hline Std. Dev. & 0.149 & 0.176 & 0.180 & 0.179 & 0.185 & 0.116 & 0.134 & 0.146 & 0.0161 & 0.178 \\
\hline Skewness & 0.270 & 0.066 & 0.054 & 0.054 & 0.115 & 0.149 & 0.206 & -1.419 & -0.662 & 0.702 \\
\hline Kurtosis & 1.827 & 2.003 & 1.915 & 1.922 & 1.928 & 2.093 & 2.929 & 7.994 & 3.389 & 2.411 \\
\hline Jarque-Bera & 3.680 & 2.232 & 2.624 & 2.590 & 2.655 & 2.012 & 0.388 & 72.875 & 4.202 & 5.126 \\
\hline $\mathrm{P}$ Values & 0.159 & 0.328 & 0.269 & 0.274 & 0.265 & 0.366 & 0.824 & 0.000 & 0.122 & 0.077 \\
\hline Coeff. Variation & 0.043 & 0.043 & 0.045 & 0.045 & 0.046 & 0.022 & 0.165 & 0.002 & 0.008 & 0.178 \\
\hline \multicolumn{11}{|l|}{ Correlations } \\
\hline $\mathrm{M}_{1}$ & 1.000 & 0.991 & 0.992 & 0.992 & 0.995 & 0.963 & -0.344 & -0.499 & 0.135 & 0.797 \\
\hline $\mathrm{M}_{3}$ & 0.991 & 1.000 & 0.999 & 0.999 & 0.999 & 0.959 & -0.355 & -0.526 & 0.120 & 0.730 \\
\hline $\mathrm{L}_{1}$ & 0.992 & 0.999 & 1.000 & 1.000 & 0.999 & 0.963 & -0.364 & -0.532 & 0.130 & 0.736 \\
\hline $\mathrm{L}_{2}$ & 0.992 & 0.999 & 1.000 & 1.000 & 0.999 & 0.963 & -0.363 & -0.532 & 0.131 & 0.737 \\
\hline $\mathrm{NM}_{3}$ & 0.995 & 0.999 & 0.999 & 0.999 & 1.000 & 0.961 & -0.358 & -0.524 & 0.126 & 0.748 \\
\hline GDP & 0.963 & 0.959 & 0.963 & 0.963 & 0.961 & 1.000 & -0.281 & -0.468 & 0.095 & 0.753 \\
\hline CMR & -0.344 & -0.355 & -0.364 & -0.363 & -0.358 & -0.281 & 1.000 & 0.858 & -0.070 & -0.090 \\
\hline TBR & -0.499 & -0.526 & -0.532 & -0.532 & -0.524 & -0.468 & 0.858 & 1.000 & 0.028 & -0.144 \\
\hline REERTB & 0.135 & 0.120 & 0.130 & 0.131 & 0.126 & 0.095 & -0.070 & 0.028 & 1.000 & 0.263 \\
\hline CNXNifty & 0.797 & 0.730 & 0.736 & 0.737 & 0.748 & 0.753 & -0.090 & -0.144 & 0.263 & 1.000 \\
\hline
\end{tabular}


Table 2. Regression Results: (Newey West HAC Standard Error and Covariance ( lag truncation=3))

\begin{tabular}{|c|c|c|c|c|c|c|c|c|c|c|}
\hline \multirow{2}{*}{ 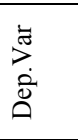 } & \multicolumn{5}{|c|}{$\begin{array}{c}\text { Panel A: } \\
\text { Independent Variables }\end{array}$} & \multicolumn{5}{|c|}{$\begin{array}{c}\text { Panel B } \\
\text { Independent Variables }\end{array}$} \\
\hline & $\mathrm{C}$ & GDP & CMR & REERT & CNXNifty & $\mathrm{C}$ & GDP & TBR & REERT & CNXNifty \\
\hline \multirow{4}{*}{$\mathrm{M}_{1}$} & $-2.25^{*}$ & $1.014 *$ & $-0.12 *$ & 0.006 & $0.1649^{*}$ & $-2.08^{*}$ & $0.953^{*}$ & $-0.12 *$ & 0.0874 & $0.186^{*}$ \\
\hline & $(-4.33)$ & $(17.01)$ & $(-3.94)$ & $(0.030)$ & $(4.700)$ & $(-3.53)$ & (12.63) & $(-2.92)$ & $(0.375)$ & (4.673) \\
\hline & $(0.000)$ & $(0.000)$ & $(0.000)$ & $(0.976)$ & $(0.000)$ & $(0.00)$ & $(0.000)$ & $(0.005$ & $(0.709)$ & $(0.000)$ \\
\hline & \multicolumn{5}{|c|}{$\mathrm{R}^{2}=0.949$ Adj $\mathrm{R}^{2}=0.945 \mathrm{DW}=1.158 \quad \mathrm{~F}=224.645 \mathrm{P}=0.000$} & \multicolumn{5}{|c|}{$\mathrm{R}^{2}=0.946$, Adj $\mathrm{R}^{2}=0.945, \mathrm{DW}=1.58, \mathrm{~F}=226.15 \mathrm{P}=0.000$} \\
\hline \multirow[t]{4}{*}{$\mathrm{M}_{3}$} & $-3.93 *$ & $1.32 *$ & $-0.13 * *$ & 0.188 & 0.0383 & $-3.70 *$ & $1.298^{*}$ & $-0.14 * *$ & 0.275 & 0.065 \\
\hline & $(-4.73)$ & $(14.11)$ & $(-2.63)$ & $(0.656))$ & $(0.737)$ & $(-4.68)$ & $(12.11)$ & $(-3.02)$ & $(0.908)$ & $(1.222)$ \\
\hline & $(0.000)$ & $(0.000)$ & $(0.011)$ & $(0.515)$ & $(0.464)$ & $(0.000$ & $(0.000)$ & $(0.004)$ & $(0.368)$ & $(0.228)$ \\
\hline & \multicolumn{5}{|c|}{$\mathrm{R}^{2}=0.929$ Adj $\mathrm{R}^{2}=0.922 \mathrm{DW}=1.497 \quad \mathrm{~F}=156.136 \mathrm{P}=0.000$} & \multicolumn{5}{|c|}{$\mathrm{R}^{2}=0.930$, Adj $\mathrm{R}^{2}=0.92 \mathrm{DW}=1.49, \quad \mathrm{~F}=159.43 \mathrm{P}=0.000$} \\
\hline \multirow[t]{4}{*}{$\mathrm{L}_{1}$} & $-4.24 *$ & $1.39 *$ & $-0.14 *$ & 0.284 & 0.046 & $-4.01 *$ & $1.318^{*}$ & $-0.16^{*}$ & 0.038 & 0.075 \\
\hline & $(-5.44)$ & $(14.57)$ & $(3.033)$ & $(1.127)$ & $(0.981)$ & $(-4.94)$ & $(12.10)$ & $(-2.911)$ & $(1.323)$ & $(1.465)$ \\
\hline & $(0.000$ & $(0.000)$ & $(0.004)$ & $(0.265)$ & $(0.333$ & $(0.000$ & $(0.000)$ & $(0.005)$ & $(0.192)$ & $(0.149)$ \\
\hline & \multicolumn{5}{|c|}{$\mathrm{R}^{2}=0.938 \quad \operatorname{Adj} \mathrm{R}^{2}=0.933 \mathrm{DW}=1.604 \mathrm{~F}=183.21 \mathrm{P}=0.000$} & \multicolumn{5}{|c|}{$\mathrm{R}^{2}=0.939 \mathrm{Adj} \mathrm{R}^{2}=0.934 \mathrm{DW}=1.59, \quad \mathrm{~F}=186.74 \mathrm{P}=0.000$} \\
\hline \multirow[t]{4}{*}{$\mathrm{L}_{2}$} & -4.194 & 1.387 & -0.140 & 0.288 & 0.0459 & $-3.94 *$ & $1.308^{*}$ & $-0.16^{*}$ & 0.384 & 0.073 \\
\hline & $(-5.41)$ & $(-2.99)$ & $(-2.99)$ & $(0.684)$ & $(0.784)$ & $(-4.96)$ & $(12.07)$ & $(-2.93)$ & $(1.343)$ & $(1.469)$ \\
\hline & $(0.000)$ & $(0.000)$ & $(0.004)$ & $(0.497)$ & $(0.437)$ & $(0.00)$ & $(0.000)$ & $(0.005)$ & $(0.186)$ & $(0.148)$ \\
\hline & \multicolumn{5}{|c|}{$\mathrm{R}^{2}=0.938 \mathrm{Adj} \mathrm{R}^{2}=0.933 \mathrm{DW}=1.599 \mathrm{~F}=182.014 \mathrm{P}=0.000$} & \multicolumn{5}{|c|}{$\mathrm{R}^{2}=0.939$, Adj $\mathrm{R}^{2}=0.934 \mathrm{DW}=1.59 \mathrm{~F}=186.028 \mathrm{P}=0.000$} \\
\hline \multirow[t]{4}{*}{$\mathrm{NM}_{3}$} & $-4.07 *$ & $1.397 *$ & $-0.14 *$ & 0.173 & 0.083 & $-3.84 *$ & $1.316^{*}$ & $-0.14 *$ & 0.272 & $0.111 * *$ \\
\hline & $(-5.17)$ & $(14.52)$ & $(-3.05)$ & $(0.623)$ & $(1.664)$ & $(-4.80)$ & $(11.86)$ & $(-2.90)$ & $(0.887)$ & $(2.076)$ \\
\hline & $(0.000)$ & $(0.000)$ & $(0.004)$ & $(0.536)$ & $(0.103)$ & $(0.00)$ & $(0.000)$ & $(0.006)$ & $(0.379)$ & $(0.043$ \\
\hline & \multicolumn{5}{|c|}{$\mathrm{R}^{2}=0.938 \mathrm{Adj} \mathrm{R}^{2}=0.931 \mathrm{DW}=1.548 \mathrm{~F}=175.469 \mathrm{P}=0.000$} & \multicolumn{5}{|c|}{$\mathrm{R}^{2}=0.9386 \mathrm{Adj} \mathrm{R}^{2}=0.934 \mathrm{DW}=1.55 \mathrm{~F}=178.150 \mathrm{P}=0.000$} \\
\hline
\end{tabular}

$*, * *, * *$ Denotes $1 \%, 5 \%$ and $10 \%$ significance level respectively. Obtained ' $\mathrm{t}$ ' statistics and $\mathrm{p}$ values are given the parenthesis respectively.

Table 3. Unit Root Tests

\begin{tabular}{|c|c|c|c|c|c|c|c|c|}
\hline \multirow[t]{2}{*}{ Variable } & \multicolumn{2}{|c|}{$\begin{array}{c}\text { PP } \\
\text { Test Level }\end{array}$} & \multicolumn{2}{|c|}{$\begin{array}{c}\text { PP Test } \\
\text { First Difference }\end{array}$} & \multicolumn{2}{|c|}{$\begin{array}{c}\text { KPSS Test } \\
\text { Level }\end{array}$} & \multicolumn{2}{|c|}{$\begin{array}{c}\text { KPSS Test } \\
\text { First Difference }\end{array}$} \\
\hline & $\mathrm{C}$ & $C \& \mathrm{~T}$ & $\mathrm{C}$ & $C \& T$ & $\mathrm{C}$ & $\mathrm{C} \& \mathrm{~T}$ & $\mathrm{C}$ & $C \& \mathrm{~T}$ \\
\hline $\mathrm{M}_{1}$ & $\begin{array}{c}2.770(14) \\
(1.00)\end{array}$ & $\begin{array}{c}-2.98(18) \\
(0.148)\end{array}$ & $\begin{array}{c}-9.279(17) \\
(0.000) *\end{array}$ & $\begin{array}{c}-13.46(15) \\
(0.000) *\end{array}$ & $0.980(5)$ & $\begin{array}{c}0.231 \\
(13)\end{array}$ & $0.421(05) *$ & $0.137(14) *$ \\
\hline $\mathrm{M}_{3}$ & $\begin{array}{c}1.364(12) \\
(0.999)\end{array}$ & $\begin{array}{c}-1.138(7) \\
(0.912)\end{array}$ & $\begin{array}{c}-3.946(80) \\
(0.000) *\end{array}$ & $\begin{array}{c}-5.951(21) \\
(0.000) *\end{array}$ & $0.989(5)$ & $0.123(5)$ & $0.246(10) *$ & $0.131(12) *$ \\
\hline $\mathrm{L}_{1}$ & $\begin{array}{c}1.623(19) \\
(0.999)\end{array}$ & $\begin{array}{c}-3.12(10) \\
(0.113)\end{array}$ & $\begin{array}{c}-9.269(25) \\
(0.000) *\end{array}$ & $\begin{array}{c}-9.541(24) \\
(0.000) *\end{array}$ & $0.994(5)$ & $0.144(3)$ & $0.283(20) *$ & $0.173(19) *$ \\
\hline $\mathrm{L}_{2}$ & $\begin{array}{c}1.582(19) \\
(0.999)\end{array}$ & $\begin{array}{c}-3.101(9) \\
(0.117)\end{array}$ & $\begin{array}{c}-9.366(26) \\
(0.000)\end{array}$ & $\begin{array}{c}-9.461(24) \\
(0.000)\end{array}$ & $0.994(5)$ & $0.148(3)$ & $0.278(20) *$ & $0.108(19) *$ \\
\hline $\mathrm{NM}_{3}$ & $\begin{array}{c}4.544(44) \\
(1.000)\end{array}$ & $\begin{array}{c}-1.62(12) \\
(0.771)\end{array}$ & $\begin{array}{c}-7.451(50) \\
(0.000) *\end{array}$ & $\begin{array}{l}-7.45(50) \\
(0.000) *\end{array}$ & $0.991(5)$ & $0.187(8)$ & $0.407(46) *$ & $0.500(81) *$ \\
\hline CMR & $\begin{array}{c}-3.478(1) \\
(0.013)\end{array}$ & $\begin{array}{c}-3.765(1) \\
(0.007)\end{array}$ & $\begin{array}{c}-11.44(18) \\
(0.000) *\end{array}$ & $\begin{array}{c}-12.06(20) \\
(0.000) *\end{array}$ & 0.407 (4) & $0.102(4)$ & $0.097(9) *$ & $0.095(9) *$ \\
\hline TBR & $\begin{array}{c}-0.939(1) \\
(0.707) \\
\end{array}$ & $\begin{array}{c}-1.633(1) \\
(0.766) \\
\end{array}$ & $\begin{array}{l}-3.806(0) \\
(0.005) *\end{array}$ & $\begin{array}{c}-3.584(1) \\
(0.04) *\end{array}$ & $0.344(5)$ & $0.096(4)$ & $0.177(1) *$ & $0.132(1) *$ \\
\hline REERT & $\begin{array}{c}-2.218(2) \\
(0.203)\end{array}$ & $\begin{array}{c}-1.973(2) \\
(0.602)\end{array}$ & $\begin{array}{l}-5.332(1) \\
(0.000) *\end{array}$ & $\begin{array}{c}-5.661(1) \\
(0.000) *\end{array}$ & $0.162(4)$ & $0.948(4)$ & $0.163(1) *$ & $0.086(0) *$ \\
\hline $\begin{array}{c}\text { CNXNIFT } \\
\mathrm{Y} \\
\end{array}$ & $\begin{array}{c}-0.962(1) \\
(0.759) \\
\end{array}$ & $\begin{array}{l}-2.02(0) \\
(0.577)\end{array}$ & $\begin{array}{l}-5.004(3) \\
(0.001) *\end{array}$ & $\begin{array}{l}-4.91(15) \\
(0.0009) *\end{array}$ & $0.642(3)$ & $0.174(5)$ & $0.9395(2) *$ & $0.062(2) *$ \\
\hline
\end{tabular}

* **, ** Denotes $1 \%, 5 \%$ and $10 \%$ significance level respectively stands for with constants and $\mathrm{C} \& \mathrm{~T}$ for with constant and trend. For PP tests and KPSS the brackets represent the bandwidth Newey- West using Bartlett kernel. For PP tests p values in the parenthesis. The critical values for KPSS LM statistics is at level with constant term is at $1 \%, 5 \%, 10 \%$ significance level are $0.739,0.463$ and 0.347 respectively and for constant and trend term it is $0.216,0.146$ and 0.119 . Similar 
Table 4. Johansen Juselius Cointegration Tests

\begin{tabular}{|c|c|c|c|c|c|c|c|c|c|c|}
\hline \multirow{2}{*}{$\begin{array}{l}\text { Cointg. } \\
\text { Equation }\end{array}$} & \multirow{2}{*}{$\begin{array}{l}\text { Hypothesis: } \\
\text { Trace } \\
\text { Stat. }\end{array}$} & \multirow{2}{*}{$\begin{array}{l}\text { Hypothesis: } \\
\text { Max } \\
\text { Stat. }\end{array}$} & \multicolumn{4}{|c|}{ Panel A ( with Constant) } & \multicolumn{4}{|c|}{ Panel B ( With Trend) } \\
\hline & & & $\begin{array}{c}\lambda \text { Trace } \\
\text { Stat. }\end{array}$ & $\begin{array}{c}\mathrm{P} \\
\text { value }\end{array}$ & $\begin{array}{c}\lambda \operatorname{Max} \\
\text { Stat. }\end{array}$ & $\begin{array}{c}\mathrm{P} \\
\text { Value }\end{array}$ & $\begin{array}{c}\lambda \\
\text { Trace } \\
\text { Stat. }\end{array}$ & $\begin{array}{c}\mathrm{p} \\
\text { Value }\end{array}$ & $\begin{array}{c}\lambda \text { Max } \\
\text { Stat. }\end{array}$ & $\begin{array}{c}\mathrm{p} \\
\text { Value }\end{array}$ \\
\hline \multirow{4}{*}{$\begin{array}{c}\mathrm{M}_{1}, \mathrm{GDP}, \\
\text { CMR, } \\
\text { REERT, } \\
\text { CNXNifty }\end{array}$} & Ho:r $=0, \mathrm{H}_{1}: \mathrm{r}>0$ & Ho:r $=0, \mathrm{H}_{1}: \mathrm{r}=1$ & $127.530 *$ & 0.000 & $50.327 *$ & 0.000 & $141.624 *$ & 0.000 & $46.544 *$ & 0.005 \\
\hline & Ho:r $\leq 1, \mathrm{H}_{1}: \mathrm{r}>1$ & Ho: $\mathrm{r}=1, \mathrm{H}_{1}: \mathrm{r}=2$ & $17.003 *$ & 0.001 & $41.319^{*}$ & 0.000 & $93.250 *$ & 0.000 & 44.764 & 0.071 \\
\hline & Ho:r $\leq 2, \mathrm{H}_{1}: \mathrm{r}>2$ & Ho: $r=2, H_{1}: r=3$ & $95.684 *$ & 0.044 & 18.162 & 0.171 & $50.946^{*}$ & 0.006 & 23.915 & 0.088 \\
\hline & Ho:r $\leq 3, \mathrm{H}_{1}: \mathrm{r}>3$ & Ho:r $=3, H_{1}: r=4$ & 17.321 & 0.114 & 146.7 & 0.078 & 23.041 & 0.053 & 15.171 & 0.154 \\
\hline \multirow{5}{*}{$\begin{array}{c}\mathrm{M}_{1} \text {, GDP, } \\
\text { TBR, } \\
\text { REERT, } \\
\text { CNXNifty }\end{array}$} & Ho:r $=0, \mathrm{H}_{1}: \mathrm{r}>0$ & Ho:r $=0, \mathrm{H}_{1}: \mathrm{r}=1$ & $141.230 *$ & 0.000 & $61.795^{*}$ & 0.000 & $155.957 *$ & 0.000 & $66.025^{*}$ & 0.000 \\
\hline & Ho:r $\leq 1, \mathrm{H}_{1}: \mathrm{r}>1$ & Ho:r $=1, \mathrm{H}_{1}: \mathrm{r}=2$ & $79.435^{*}$ & 0.000 & $42.244 *$ & 0.000 & $89.938^{*}$ & 0.001 & $43.927 *$ & 0.001 \\
\hline & Ho:r $\leq 2, \mathrm{H}_{1}: \mathrm{r}>2$ & Ho: $\mathrm{r}=2, \mathrm{H}_{1}: \mathrm{r}=3$ & $32.191 *$ & 0.030 & 19.302 & 0.132 & $46.008 *$ & 0.003 & $21.401 *$ & 0.021 \\
\hline & Ho: $\mathrm{r} \leq 3, \mathrm{H}_{1}: \mathrm{r}>3$ & Ho:r $=3, \mathrm{H}_{1}: \mathrm{r}=4$ & 18.086 & 0.097 & 13.396 & 0.140 & $25.547 *$ & 0.035 & 14.023 & 0.251 \\
\hline & Ho:r $\leq 4, \mathrm{H}_{1}: \mathrm{r}>4$ & Ho: $\mathrm{r}=4, \mathrm{H}_{1}: \mathrm{r}=5$ & 4.492 & 0.344 & 4.492 & 0.344 & $12.543 *$ & 0.024 & $11.523 *$ & 0.002 \\
\hline \multirow{4}{*}{$\begin{array}{l}\mathrm{M}_{3} \text {, GDP, } \\
\text { CMR, } \\
\text { REERT, } \\
\text { CNXNifty }\end{array}$} & Ho: $r=0, H_{1}: r>0$ & Ho:r $=0, \mathrm{H}_{1}: \mathrm{r}=1$ & $105.580 *$ & 0.000 & $37.776^{*}$ & 0.002 & $130.037 *$ & 0.000 & $42.981 *$ & 0.014 \\
\hline & Ho:r $\leq 1, \mathrm{H}_{1}: \mathrm{r}>1$ & Ho:r=1, $\mathrm{H}_{1}: \mathrm{r}=2$ & $67.784 *$ & 0.001 & $31.312 *$ & 0.021 & $87.875^{*}$ & 0.000 & $32.907 *$ & 0.040 \\
\hline & Ho:r $\leq 2, \mathrm{H}_{1}: \mathrm{r}>2$ & Ho:r $=2, \mathrm{H}_{1}: \mathrm{r}=3$ & $36.272 *$ & 0.038 & 16.759 & 0.244 & $34.909 *$ & 0.002 & $29.409 *$ & 0.016 \\
\hline & Ho: $\mathrm{r} \leq 3, \mathrm{H}_{1}: \mathrm{r}>3$ & Ho:r $=3, \mathrm{H}_{1}: \mathrm{r}=4$ & 19.42 & 0.063 & 14.171 & 0.091 & 25.507 & 0.054 & 14.119 & 0.246 \\
\hline \multirow{5}{*}{$\begin{array}{c}\mathrm{M}_{3} \text {, GDP, } \\
\text { TBR, } \\
\text { REERT, } \\
\text { CNXNifty }\end{array}$} & Ho:r $=0, \mathrm{H}_{1}: \mathrm{r}>0$ & Ho:r $=0, \mathrm{H}_{1}: \mathrm{r}=1$ & $170.182 *$ & 0.000 & $81.628^{*}$ & 0.000 & $124.004 *$ & 0.000 & $44.367^{*}$ & 0.002 \\
\hline & Ho:r $\leq 1, \mathrm{H}_{1}: \mathrm{r}>1$ & Ho: $\mathrm{r}=1, \mathrm{H}_{1}: \mathrm{r}=2$ & $88.956^{*}$ & 0.000 & $35.866^{*}$ & 0.005 & $79.052 *$ & 0.000 & $35.812 *$ & 0.003 \\
\hline & Ho:r $\leq 2, \mathrm{H}_{1}: \mathrm{r}>2$ & Ho:r $=2, \mathrm{H}_{1}: \mathrm{r}=3$ & $33.089 *$ & 0.000 & $28.118^{*}$ & 0.007 & $43.844 *$ & 0.007 & $25.231 *$ & 0.025 \\
\hline & Ho: $\mathrm{r} \leq 3, \mathrm{H}_{1}: \mathrm{r}>3$ & Ho:r $=3, H_{1}: r=4$ & $24.970 *$ & 0.010 & $18.374 *$ & 0.019 & $20.610 *$ & 0.007 & $18.069^{*}$ & 0.011 \\
\hline & Ho:r $\leq 4, \mathrm{H}_{1}: \mathrm{r}>4$ & Ho:r $=4, \mathrm{H}_{1}: \mathrm{r}=5$ & 6.446 & 0.959 & 6.446 & 0.159 & 2.541 & 0.119 & 2.541 & 0.119 \\
\hline \multirow{5}{*}{$\begin{array}{c}\mathrm{L}_{1}, \mathrm{GDP}, \\
\text { CMR, } \\
\text { REERT, } \\
\text { CNXNifty }\end{array}$} & Ho: $\mathrm{r}=0, \mathrm{H}_{1}: \mathrm{r}>0$ & Ho:r $=0, \mathrm{H}_{1}: \mathrm{r}=1$ & $136.924 *$ & 0.000 & 61.426 & $0.000^{*}$ & $136.973 *$ & 0.000 & $61.428^{*}$ & 0.000 \\
\hline & Ho:r $\leq 1, \mathrm{H}_{1}: \mathrm{r}>1$ & Ho:r=1, $\mathrm{H}_{1}: \mathrm{r}=2$ & $75.493 *$ & 0.000 & $31.846^{*}$ & 0.018 & $75.495 *$ & 0.02 & $31.848^{*}$ & 0.018 \\
\hline & Ho:r $\leq 2, \mathrm{H}_{1}: \mathrm{r}>2$ & Ho:r $=2, H_{1}: r=3$ & $43.646^{*}$ & 0.022 & 19.721 & 0.110 & $43.646^{*}$ & 0.005 & 19.721 & 0.110 \\
\hline & Ho:r $\leq 3, \mathrm{H}_{1}: \mathrm{r}>3$ & Ho:r=3, $\mathrm{H}_{1}: \mathrm{r}=4$ & 23.923 & 0.075 & 13.861 & 0.101 & $23.925 *$ & 0.015 & 13.860 & 0.101 \\
\hline & Ho: $\mathrm{r} \leq 4, \mathrm{H}_{1}: \mathrm{r}>4$ & Ho:r $=4, \mathrm{H}_{1}: \mathrm{r}=5$ & 4.004 & 0.067 & 9.064 & 0.054 & 10.064 & 0.136 & 10.004 & 0.135 \\
\hline \multirow{4}{*}{$\begin{array}{c}\mathrm{L}_{1}, \mathrm{GDP}, \\
\text { TBR, } \\
\text { REERT, } \\
\text { CNXNifty }\end{array}$} & Ho:r $=0, \mathrm{H}_{1}: \mathrm{r}>0$ & Ho:r $=0, \mathrm{H}_{1}: \mathrm{r}=1$ & $100.386^{*}$ & 0.000 & $36.734 *$ & 0.024 & $114.820^{*}$ & 0.000 & $44.478^{*}$ & 0.008 \\
\hline & Ho:r $\leq 1, \mathrm{H}_{1}: \mathrm{r}>1$ & Ho:r $=1, \mathrm{H}_{1}: \mathrm{r}=2$ & $63.832 *$ & 0.005 & $28.872 *$ & 0.050 & $70.340^{*}$ & 0.012 & $32.788^{*}$ & 0.041 \\
\hline & Ho: $\mathrm{r} \leq 2, \mathrm{H}_{1}: \mathrm{r}>2$ & Ho:r $=2, H_{1}: r=3$ & $35.275^{*}$ & 0.049 & 20.931 & 0.075 & 32.337 & 0.181 & 16.820 & 0.473 \\
\hline & Ho:r $\leq 3, \mathrm{H}_{1}: \mathrm{r}>3$ & Ho:r $=3, H_{1}: r=4$ & 14.804 & 0.769 & 8.354 & 0.806 & 21.237 & 0.190 & 16.216 & 0.240 \\
\hline \multirow{3}{*}{$\begin{array}{c}\mathrm{L}_{2} \text {, GDP, } \\
\text { CMR, } \\
\text { REERT, } \\
\text { CNXNifty }\end{array}$} & Ho:r $=0, \mathrm{H}_{1}: \mathrm{r}>0$ & Ho:r $=0, \mathrm{H}_{1}: \mathrm{r}=1$ & $92.701 *$ & 0.002 & $33.479 *$ & 0.041 & $113.839 *$ & 0.000 & $40.183 *$ & 0.030 \\
\hline & Ho:r $\leq 1, \mathrm{H}_{1}: \mathrm{r}>1$ & Ho: $\mathrm{r}=1, \mathrm{H}_{1}: \mathrm{r}=2$ & $59.221 *$ & 0.016 & $29.0146^{*}$ & 0.043 & 73.638 & 0.076 & $32.186^{*}$ & 0.045 \\
\hline & Ho: $\mathrm{r} \leq 2, \mathrm{H}_{1}: \mathrm{r}>2$ & Ho:r $=2, H_{1}: r=3$ & 30.057 & 0.161 & 13.341 & 0.472 & 211.472 & 0.069 & 22.165 & 0.141 \\
\hline \multirow{4}{*}{$\begin{array}{c}\mathrm{L}_{2}, \mathrm{GDP}, \\
\text { TBR, } \\
\text { REERT, } \\
\text { CNXNifty }\end{array}$} & Ho:r $=0, \mathrm{H}_{1}: \mathrm{r}>0$ & Ho:r $=0, \mathrm{H}_{1}: \mathrm{r}=1$ & 99.293* & 0.004 & $36.04 *$ & 0.035 & $114.894 *$ & 0.002 & $44.863^{*}$ & 0.000 \\
\hline & Ho:r $\leq 1, \mathrm{H}_{1}: \mathrm{r}>1$ & Ho:r $=1, \mathrm{H}_{1}: \mathrm{r}=2$ & $63.184^{*}$ & 0.006 & $22.590 *$ & 0.050 & $70.030 *$ & 0.014 & 31.863 & 0.537 \\
\hline & Ho: $\mathrm{r} \leq 2, \mathrm{H}_{1}: \mathrm{r}>2$ & Ho:r $=2, \mathrm{H}_{1}: \mathrm{r}=3$ & 35.593 & 0.545 & 20.456 & 0.080 & 38.167 & 0.138 & 17.903 & 0.384 \\
\hline & Ho:r $\leq 3, \mathrm{H}_{1}: \mathrm{r}>3$ & Ho:r $=3, \mathrm{H}_{1}: \mathrm{r}=4$ & 15.156 & 0.212 & 8.753 & 0.054 & 20.167 & 0.213 & 13.519 & 0.288 \\
\hline \multirow{4}{*}{$\begin{array}{c}\mathrm{NM}_{3}, \mathrm{GDP}, \\
\text { CMR, } \\
\text { REERT, } \\
\text { CNXNifty }\end{array}$} & Ho: $\mathrm{r}=0, \mathrm{H}_{1}: \mathrm{r}>0$ & Ho:r $=0, \mathrm{H}_{1}: \mathrm{r}=1$ & $104.860 *$ & 0.001 & $41.669 *$ & 0.006 & $24.384 *$ & 0.000 & $45.677^{*}$ & 0.006 \\
\hline & Ho:r $\leq 1, \mathrm{H}_{1}: \mathrm{r}>1$ & Ho:r $=1, \mathrm{H}_{1}: \mathrm{r}=2$ & $62.190 *$ & 0.036 & $26.631 *$ & 0.046 & $78.708 *$ & 0.001 & 29.686 & 0.097 \\
\hline & Ho: $\mathrm{r} \leq 2, \mathrm{H}_{1}: \mathrm{r}>2$ & Ho:r $=2, \mathrm{H}_{1}: \mathrm{r}=3$ & $36.209 *$ & 0.036 & 17.681 & 0.185 & $49.012 *$ & 0.011 & 24.521 & 0.073 \\
\hline & Ho:r $\leq 3, \mathrm{H}_{1}: \mathrm{r}>3$ & Ho:r $=3, \mathrm{H}_{1}: \mathrm{r}=4$ & 18.829 & 0.077 & 13.348 & 0.125 & 24.550 & 0.728 & 13.257 & 0.307 \\
\hline \multirow{4}{*}{$\begin{array}{c}\mathrm{NM}_{3}, \mathrm{GDP}, \\
\text { TBR, } \\
\text { REERT, } \\
\text { CNXNifty }\end{array}$} & Ho:r $=0, \mathrm{H}_{1}: \mathrm{r}>0$ & Ho:r $=0, \mathrm{H}_{1}: \mathrm{r}=1$ & $131.128^{*}$ & 0.000 & $64.994 *$ & 0.000 & $110.277^{*}$ & 0.000 & $40.246^{*}$ & 0.027 \\
\hline & Ho:r $\leq 1, \mathrm{H}_{1}: \mathrm{r}>1$ & Ho:r $=1, \mathrm{H}_{1}: \mathrm{r}=2$ & $66.134 *$ & 0.003 & $27.743 *$ & 0.048 & $70.0264 *$ & 0.001 & $27.013 *$ & 0.012 \\
\hline & Ho:r $\leq 2, \mathrm{H}_{1}: \mathrm{r}>2$ & Ho:r $=2, H_{1}: r=3$ & 38.381 & 0.022 & 24.201 & 0.027 & $32.953 *$ & 0.004 & 23.323 & 0.024 \\
\hline & Ho:r $\leq 3, \mathrm{H}_{1}: \mathrm{r}>3$ & Ho:r $=3, \mathrm{H}_{1}: \mathrm{r}=4$ & 14.179 & 0.277 & 9.086 & 0.425 & 14.629 & 0.067 & 12.142 & 0.105 \\
\hline
\end{tabular}

$*, * *, * *$ Denotes $1 \%, 5 \%$ and $10 \%$ significance level respectively. Critical Values are used from Osterwald-Lenum (1992). 
Table 5. Error Correction Models:

\begin{tabular}{|c|c|c|c|c|}
\hline ECM Equations & Interest rate Variables & Coefficient of ECM(-1) & T Statistics & P values \\
\hline $\mathrm{M}_{1}$ & CMR & -0.405 & -0.973 & 0.342 \\
\hline $\mathrm{M}_{1}$ & TBR & -0.182 & -0.377 & 0.709 \\
\hline $\mathrm{M}_{3}$ & CMR & 0.003 & 0.008 & 0.993 \\
\hline $\mathrm{M}_{3}$ & TBR & 0.377 & 0.791 & 0.438 \\
\hline $\mathrm{L}_{1}$ & $\mathrm{CMR}$ & -0.083 & -0.404 & 0.647 \\
\hline $\mathrm{L}_{1}$ & $\mathrm{TBR}$ & -1.173 & -1.77 & 0.162 \\
\hline $\mathrm{L}_{2}$ & $\mathrm{CMR}$ & -0.855 & -1.216 & 0.237 \\
\hline $\mathrm{L}_{2}$ & $\mathrm{TBR}$ & -0.289 & -0.625 & 0.538 \\
\hline $\mathrm{NM}_{3}$ & $\mathrm{CMR}$ & -0.342 & -0.797 & 0.434 \\
\hline $\mathrm{NM}_{3}$ & $\mathrm{TBR}$ & -0.002 & -0.009 & 0.996 \\
\hline
\end{tabular}

$*, * *, * *$ Denotes $1 \%, 5 \%$ and $10 \%$ significance level respectively.

Table 6. Granger Causality Tests

\begin{tabular}{|c|c|c|c|c|c|c|c|}
\hline Hypothesis e. g. & es not Grange & use $X$. ; & $\mathrm{H}_{1}: \mathrm{Y} \quad \mathrm{Gr}$ & cause $X, L a g=4$ : & & & \\
\hline $\begin{array}{l}\text { Direction of Causality } \\
\qquad(\mathrm{Y} \rightarrow \mathrm{X})\end{array}$ & F Statistics & $P$ value & $\begin{array}{c}\text { Causality } \\
\text { Exists }\end{array}$ & $\begin{array}{l}\text { Direction of Causality } \\
\qquad(\mathrm{Y} \rightarrow \mathrm{X})\end{array}$ & F Statistics & P Value & $\begin{array}{c}\text { Causality } \\
\text { Exists }\end{array}$ \\
\hline $\mathrm{RGDP} \rightarrow \mathrm{M}_{1}$ & $2.53 * * *$ & 0.055 & $\mathrm{Y}$ & $\mathrm{L}_{1} \rightarrow \mathrm{TBR}$ & $4.243 *$ & 0.006 & $\mathrm{Y}$ \\
\hline $\mathrm{M}_{1} \rightarrow \mathrm{GDP}$ & 1.211 & 0.322 & $\mathrm{~N}$ & $\mathrm{EERTB} \rightarrow \mathrm{L}_{1}$ & 0.838 & 0.510 & $\mathrm{~N}$ \\
\hline $\mathrm{CMR} \rightarrow \mathrm{M}_{1}$ & 1.894 & 0.131 & $\mathrm{~N}$ & $\mathrm{~L}_{1} \rightarrow$ REERTB & 0.251 & 0.907 & $\mathrm{~N}$ \\
\hline $\mathrm{M}_{1} \rightarrow \mathrm{CMR}$ & $5.457 *$ & 0.001 & $\mathrm{Y}$ & $\mathrm{CNXNIFTY} \rightarrow \mathrm{L}_{1}$ & $2.397 * * *$ & 0.067 & $\mathrm{Y}$ \\
\hline $\mathrm{TBR} \rightarrow \mathrm{M}_{1}$ & 1.872 & 0.135 & $\mathrm{~N}$ & $\mathrm{~L}_{1} \rightarrow-\mathrm{CNXNIFTY}$ & 0.792 & 0.537 & $\mathrm{~N}$ \\
\hline $\mathrm{M}_{1}$-TBR & $4.835^{* *}$ & 0.003 & $\mathrm{Y}$ & $\mathrm{GDP} \rightarrow \mathrm{L}_{2}$ & $8.247^{*}$ & 0.000 & $\mathrm{Y}$ \\
\hline REERTB $\rightarrow \mathrm{M}_{1}$ & 0.510 & 0.729 & $\mathrm{~N}$ & $\mathrm{~L}_{2} \rightarrow \mathrm{GDP}$ & $2.272 * *$ & 0.079 & Y \\
\hline $\mathrm{M}_{1} \rightarrow$ REERTB & 0.077 & 0.989 & $\mathrm{~N}$ & $\mathrm{CMR} \rightarrow \mathrm{L}_{2}$ & 0.966 & 0.437 & $\mathrm{~N}$ \\
\hline $\mathrm{CNXNIFTY}-\longrightarrow \mathrm{M}_{1}$ & $5.037^{*}$ & 0.002 & $\mathrm{Y}$ & $\mathrm{L}_{2} \rightarrow \mathrm{CMR}$ & $3.340 * *$ & 0.019 & $\mathrm{Y}$ \\
\hline $\mathrm{M}_{1} \rightarrow \mathrm{CNXNIFTY}$ & $3.152 * *$ & 0.024 & $\mathrm{Y}$ & $\mathrm{TBR} \rightarrow \mathrm{L}_{2}$ & 1.526 & 0.213 & $\mathrm{~N}$ \\
\hline $\mathrm{GDP} \rightarrow \mathrm{M}_{3}$ & $2.361 * * *$ & 0.070 & $\mathrm{Y}$ & $\mathrm{L}_{2} \rightarrow \mathrm{TBR}$ & $4.121 *$ & 0.007 & $\mathrm{Y}$ \\
\hline $\mathrm{M}_{3} \rightarrow \mathrm{GDP}$ & 1.579 & 0.199 & $\mathrm{~N}$ & REERTB $\rightarrow \mathrm{L}_{2}$ & 0.950 & 0.445 & $\mathrm{~N}$ \\
\hline $\mathrm{CMR} \rightarrow-\mathrm{M}_{3}$ & 1.390 & 0.255 & $\mathrm{~N}$ & $\mathrm{~L}_{2} \rightarrow$ REERTB & 0.284 & 0.887 & $\mathrm{~N}$ \\
\hline $\mathrm{M}_{3} \rightarrow \mathrm{CMR}$ & $5.171 *$ & 0.002 & $\mathrm{Y}$ & $\mathrm{CNXNIFTY} \rightarrow \mathrm{L}_{2}$ & $2.353 * * *$ & 0.071 & $\mathrm{Y}$ \\
\hline $\mathrm{TBR} \rightarrow \mathrm{M}_{3}$ & 0.842 & 0.5073 & $\mathrm{~N}$ & $\mathrm{~L}_{2} \rightarrow \mathrm{CNXNIFTY}$ & 0.803 & 0.531 & $\mathrm{~N}$ \\
\hline $\mathrm{M}_{3} \rightarrow \mathrm{TBR}$ & $5.229^{*}$ & 0.002 & $\mathrm{Y}$ & $\mathrm{GDP} \rightarrow \mathrm{NM}_{3}$ & $3.335^{* *}$ & 0.019 & $\mathrm{Y}$ \\
\hline $\mathrm{REERTB} \rightarrow \mathrm{M}_{3}$ & 0.486 & 0.746 & $\mathrm{~N}$ & $\mathrm{NM}_{3} \rightarrow \mathrm{GDP}$ & 1.508 & 0.219 & $\mathrm{~N}$ \\
\hline $\mathrm{M}_{3} \rightarrow$ REERTB & 0.138 & 0.967 & $\mathrm{~N}$ & $\mathrm{CMR} \rightarrow \mathrm{NM}_{3}$ & 1.220 & 0.318 & $\mathrm{~N}$ \\
\hline $\mathrm{CNXNIFTY} \rightarrow \mathrm{M}_{3}$ & $2.419 * * *$ & 0.065 & $\mathrm{Y}$ & $\mathrm{NM}_{3} \rightarrow \mathrm{CMR}$ & $5.611^{*}$ & 0.001 & $\mathrm{Y}$ \\
\hline $\mathrm{M}_{3} \rightarrow \mathrm{CNXNIFTY}$ & 1.863 & 0.136 & $\mathrm{~N}$ & $\mathrm{TBR} \rightarrow \mathrm{NM}_{3}$ & 0.544 & 0.704 & $\mathrm{~N}$ \\
\hline $\mathrm{DP} \rightarrow \mathrm{L}_{1}$ & $8.271^{*}$ & 0.000 & $\mathrm{Y}$ & $\mathrm{NM}_{3} \rightarrow \mathrm{TBR}$ & $5.462 *$ & 0.001 & $\mathrm{Y}$ \\
\hline $\mathrm{L}_{1} \rightarrow \mathrm{GDP}$ & $2.276^{* *}$ & 0.078 & $\mathrm{Y}$ & $\mathrm{REERTB} \rightarrow-\mathrm{NM}_{3}$ & 0.591 & 0.671 & $\mathrm{~N}$ \\
\hline $\mathrm{CMR} \rightarrow \mathrm{L}_{1}$ & 0.899 & 0.474 & $\mathrm{~N}$ & $\mathrm{NM}_{3} \rightarrow$ REERTB & 0.042 & 0.996 & $\mathrm{~N}$ \\
\hline $\mathrm{L}_{1}-\mathrm{CMR}$ & $3.396^{* *}$ & 0.018 & $\mathrm{Y}$ & $\mathrm{CNXNIFTY} \rightarrow \mathrm{NM}_{3}$ & $2.401 * * *$ & 0.066 & $\mathrm{Y}$ \\
\hline $\mathrm{TBR} \rightarrow \mathrm{L}_{1}$ & 1.267 & 0.299 & $\mathrm{~N}$ & $\mathrm{NM}_{3} \rightarrow \mathrm{CNXNIFTY}$ & 2.035 & 0.108 & $\mathrm{~N}$ \\
\hline
\end{tabular}

*, **, ** Denotes $1 \%, 5 \%$ and $10 \%$ significance level respectively. $\mathrm{Y}$ for Yes , $\mathrm{N}$ for No 


\section{Panel A: with CMR}

Panel B: with TBR

1. $\mathrm{M}_{1}$


2. $\mathrm{M}_{3}$


3. $\mathrm{L}_{1}$


4. $\mathrm{L}_{2}$


5. $\mathrm{NM}_{3}$
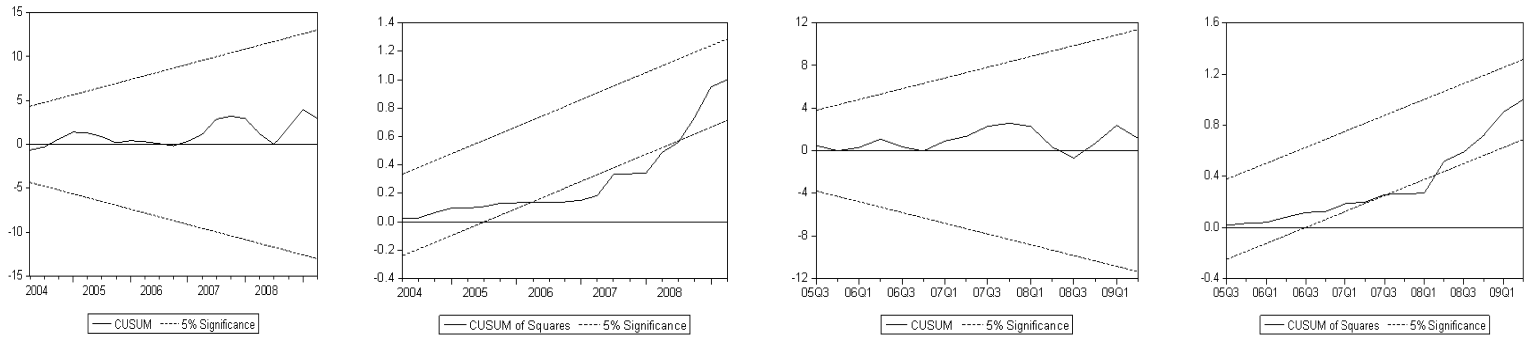

The straight line represent critical bound at 5\% significance level

Figure 1. CUSUM and CUSUMQ Test: Plot of cumulative sum of and square of recursive residual 